\title{
Perhitungan Perubahan Reaktivitas Pada Reaktor Serba Guna G.A. Siwabessy Akibat Pengoperasian Power Ramp Test Facility
}

\author{
A. Suparmi, Tuti Dwi Setyaningsih, Suharyana, Fuad Anwar, Riyatun \\ Program Studi Fisika, Fakultas Matematika dan Ilmu Pengetahuan Alam, Universitas Sebelas Maret, \\ Jl. Ir Sutami 36A Kentingan, Jebres, Surakarta 57126 \\ Email: riyatun@staff.uns.ac.id
}

\begin{abstract}
Power Ramp Test Facility (PRTF) is one of the irradiation facility contained in the Multipurpose Reactor GA Siwabessy. This facility is used to test the reactor fuel element pin-type Pressurized Water Reactor. As a result of the entry of foreign bodies cause changes reactor conditions, one of which is expressed with the amount of reactivity to assess the safety of the reactor due to the operation PRTF. PRTF operation simulation and calculation is done using software neutronics MCNP6. Test UO2 fuel enriched assumed at 5\% with constant power reactor operating at $15 \mathrm{MW}$ and test fuel pin placed on PRTF within 0,20,40,60,80,100, 120, and $140 \mathrm{~mm}$ from the centre of the reactor core. Change of reactivity values required in order to secure the reactor, maximal value is $0,5 \% \frac{\Delta k}{k}$. The calculation were obtained at each position is $(0,05675 \pm 0,00006$; $0,08633 \pm 0,00006 ; \quad 0,08058 \pm 0,00006 ; \quad 0,05675 \pm 0,00006 ; 0,03702 \pm 0,00006 ; 0,02221 \pm$ $0,00007 ; 0,01563 \pm 0,00006 ; 0,00905 \pm 0,00006) \% \frac{\Delta k}{k}$. Change of reactivity values smaller than the safe limit. Therefore, the study of reactivity changes PRTF operation to test fuel pin is secure.
\end{abstract}

Keywords: PRTF, RSG-GAS, reactivity changes

\begin{abstract}
Abstrak: Power Ramp Test Facility (PRTF) merupakan salah satu fasilitas iradiasi yang terdapat pada Reaktor Serba Guna G.A. Siwabessy. Fasilitas ini digunakan untuk menguji pin elemen bahan bakar reaktor tipe Pressurized Water Reactor. Akibat dari masuknya benda asing menyebabkan perubahan kondisi reaktor, salah satunya dinyatakan dengan besaran reaktivitas untuk mengkaji keselamatan reaktor akibat pengoperasian PRTF. Simulasi pengoperasian PRTF dan perhitungan netronik dilakukan menggunakan perangkat lunak MCNP6. Bahan bakar uji UO2 diasumsikan diperkaya sebesar 5\% dengan daya operasi reaktor konstan sebesar 15 MW. Pin bahan bakar uji diletakkan pada PRTF berjarak $0,20,40,60,80,100,120$, dan $140 \mathrm{~mm}$ dari arah pusat teras reaktor. Nilai perubahan reaktivitas yang dipersyaratkan agar reaktor aman adalah $0,5 \% \frac{\Delta k}{k}$, sedangkan nilai perubahan reaktivitas dari penelitian pada masing-masing posisi dari pusat reactor adalah $(0,05675 \pm 0,00006$; $0,08633 \pm 0,00006 ; \quad 0,08058 \pm 0,00006 ; 0,05675 \pm 0,00006 ; 0,03702 \pm 0,00006 ; 0,02221 \pm$ $0,00007 ; 0,01563 \pm 0,00006 ; 0,00905 \pm 0,00006) \% \frac{\Delta k}{k}$. Nilai perubahan reaktivitas akibat masuknya pin bahan bakar di PRTF mempunyai nilai perubahan reaktivitas $1 / 10$ kali lebih kecil daripada batas aman. Oleh karena itu, ditinjau dari kajian nilai perubahan reaktivitas maka pengoperasian PRTF untuk uji pin bahan bakar adalah aman.
\end{abstract}

Kata kunci: PRTF, RSG-GAS, perubahan reaktivitas

\section{PENDAHULUAN}

Reaktor Serba Guna G.A. Siwabessy (RSG-GAS) merupakan salah satu reaktor riset di Indonesia yang dikelola oleh Pusat Reaktor Serba Guna (PRSG). RSG-GAS telah beroperasi sejak tahun 1987 dengan daya maksimum sebesar 30 MW. Reaktor ini memiliki beberapa fasilitas iradiasi yang digunakan untuk kegiatan produksi isotop, pengujian dengan undak 
daya (power ramp test), pewarnaan batu topaz, iradiasi sampel dalam sistem rabbit, dan penelitian bahan/materi (Yulianto \& Imron, 2013).

Power Ramp Test Facility (PRTF) atau dikenal juga dengan fasilitas pengujian dengan undak daya adalah fasilitas iradiasi RSG-GAS yang digunakan untuk menguji pin elemen bahan bakar reaktor tipe Pressurized Water Reactor (PWR). Tujuan uji pin adalah untuk mengukur sifat dan perubahan struktur pada kelongsong bahan bakar, lepasan gas fisi, serta restrukturisasi bahan bakar. Pengukuran besaran reaktor akibat dioperasikannya PRTF untuk uji pin berkaitan dengan pembangkitan daya yang berubah-berubah dari bahan bakar yang diuji (Iman et al., 2015).

Dalam pelayanan iradiasi, RSG-GAS menerima sampel yang akan diiradiasi pada fasilitas iradiasi baik di dalam teras maupun diluar teras reaktor. Sampel yang dimasukkan pada fasilitas iradiasi dapat menimbulkan perubahan kondisi pada reaktor. Masuknya pin PRTF ke dalam teras reaktor dapat menimbulkan perubahan terhadap keselamatan operasi reaktor. (Sutrisno \& Purwadi, 2015). Oleh karena dapat menimbulkan perubahan kondisi keselamatan operasi reaktor, maka perlu dilakukan penelitian untuk memprediksi keselamatan reactor, salah satunya adalah perhitungan perubahan reaktivitas. Nilai reaktivitas merupakan parameter penunjang keselamatan reaktor yang menunjukkan stabil atau tidaknya suatu reaktor (DOE, 1993).

\section{METODE PENELITIAN}

\subsection{Prosedur Penelitian}

\subsubsection{Input Geometri dan Material Penyusun}

Geometri teras RSG-GAS mengacu pada penelitian Fadli et al., (2019) berupa file input geometri reaktor RSG-GAS dengan nama file CEUP. Gambar 1. merupakan gambar pin bahan bakar tipe PWR (pin bahan bakar yang diuji). Susunan input pin bahan bakar uji pada fasilitas PRTF disajikan pada Tabel 1. Parameter pada Tabel 1. digunakan sebagai input geometri pada program MCNP6. Bahan pelet atau bahan bakar uji berupa $\mathrm{UO}_{2}$ yang diperkaya sebesar 5\% dengan 36 jumlah pelet didalam pin.

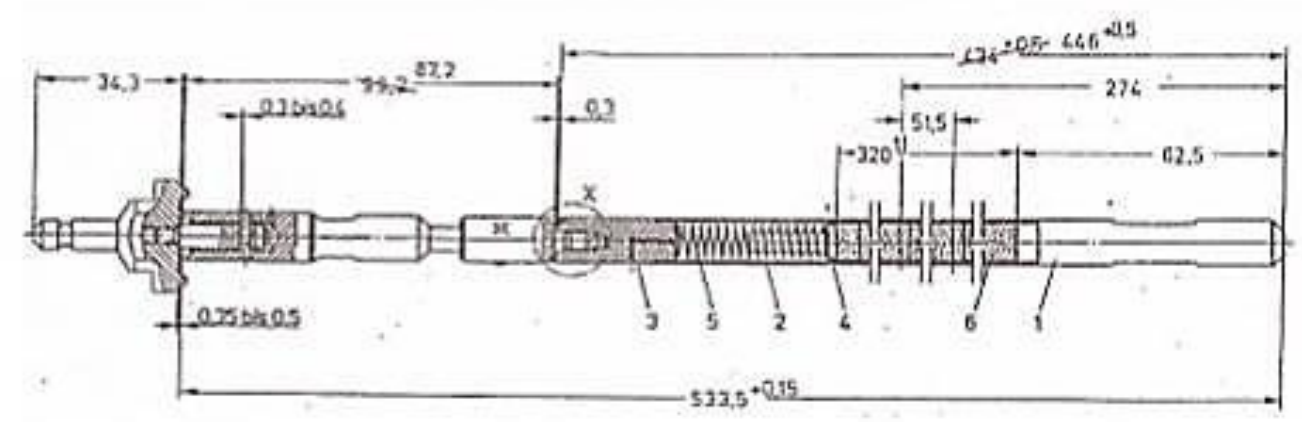

Gambar 1. Pin bahan bakar tipe PWR (Sulistyono \& Yulianto, 2013).

Tabel 1. Susunan input pin bahan bakar uji pada fasilitas PRTF (Sulistyono \& Yulianto, 2013). 


\begin{tabular}{lll}
\hline Parameter & Nilai & Satuan \\
\hline Bahan pellet & n.UO2 & \\
Panjang pellet & 0,94 & $\mathrm{~cm}$ \\
Diameter pellet & 0,89 & $\mathrm{~cm}$ \\
Fraksional densitas pellet & 0,928 & \\
Bahan kelongsong & Zircaloy-4 & \\
Panjang kelongsong & 36,65 & $\mathrm{~cm}$ \\
Diameter dalam kelongsong & 0,933 & $\mathrm{~cm}$ \\
Diameter luar kelongsong & 1,075 & $\mathrm{~cm}$ \\
Panjang total pin & 44,6 & $\mathrm{~cm}$ \\
\hline
\end{tabular}

\subsubsection{Modifikasi File Input Geometri RSG-GAS}

File input CEUP dimodifikasi pada bagian fasilitas PRTF dengan cara menyisipkan/memasukkan pin bahan bakar uji $\mathrm{UO}_{2}$. Posisi pin bahan bakar uji $\mathrm{UO}_{2}$ divariasi sebesar $(0,20,40.60 .80,100,120,140) \mathrm{mm}$ dari teras reaktor. Proses running dilakukan setiap perubahan posisi.

\subsection{Teknik Pengolahan dan Analisis Data}

\subsubsection{Perhitungan Perubahan Reaktivitas}

Nilai output yang diperoleh yaitu nilai $k_{e f f}$ dari masing-masing variasi posisi. Selanjutnya, nilai perubahan reaktivitas diperoleh dari Persamaan (1).

$$
\rho=\frac{\left(N_{0}\left(k_{e f f}\right)-N_{0}\right)}{N_{0}\left(k_{e f f}\right)}=\frac{k_{e f f}-1}{k_{e f f}}
$$

Dimana $\rho$ adalah reaktivitas, $N_{0}$ adalah jumlah netron pada generasi sebelumnya, dan $N_{0}\left(k_{\text {eff }}\right)$ adalah netron di generasi sekarang. Persamaan nilai perubahan reaktivitas ditulis pada Persamaan (2).

$$
\Delta \rho=\rho_{1}-\rho_{2}
$$

Persamaan (1) disubtitusikan ke dalam Persamaan (2) sehingga persamaan nilai perubahan reaktivitas dapat ditulis seperti pada Persamaan (3).

$$
\Delta \rho=\frac{k_{1}-k_{2}}{k_{1} \cdot k_{2}}
$$

$\Delta \rho$ adalah perubahan reaktivitas terhadap kondisi stedy state, $k_{1}$ merupakan $k_{e f f}$ pada posisi tertentu dan $k_{2}$ merupakan $k_{\text {eff }}$ RSG-GAS sebelum proses iradiasi di PRTF, sebesar $(1,10234 \pm 0,0011)$ Fadli et al.,(2019).

2.2.2. Grafik nilai $k_{\text {eff }}$ dan $\Delta \rho$ terhadap Variasi Posisi Pin Bahan Bakar Uji $\mathrm{UO}_{2}$ 
Nilai $k_{e f f}$ dan $\Delta \rho$ pada setiap posisi dibuat grafik hubungan nilai $k_{\text {eff }}$ terhadap posisi dan grafik hubungan perubahan reaktivitas terhadap posisi bahan bakar uji $\mathrm{UO}_{2}$ mendeskripsikan pengaruh dari pengkayaan bahan uji $\mathrm{UO}_{2}$ terhadap nilai $k_{\text {eff }}$ dan perubahan reaktivitas yang diperoleh pada setiap posisi.

\subsection{Diagram Alir Langkah Kerja}

Langkah kerja penelitian ini digambarkan pada diagram alir berikut.

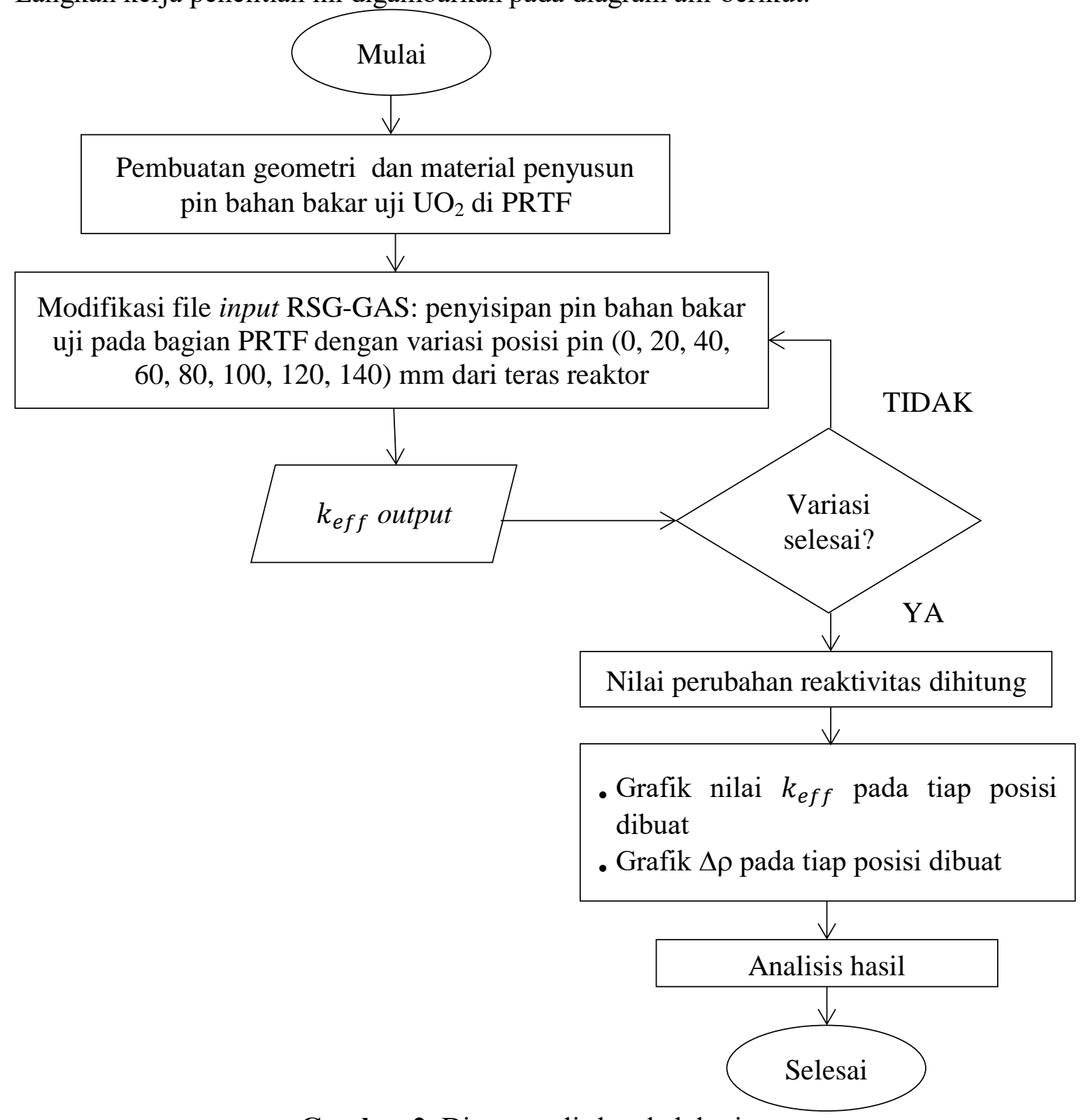

Gambar 2. Diagram alir langkah kerja.

\section{HASIL DAN PEMBAHASAN}

\subsection{Model Geometri Pin Bahan Bakar Uji}

Gambar 3. adalah geometri pin bahan bakar uji, cell berwarna kuning (1) merupakan cladding atau kelongsong berbahan Zircaloy-4. Cell berwarna merah (2) merupakan pelet 
$\mathrm{UO}_{2}$ yang diuji yang disusun sebanyak 36 buah. Cell berwarna biru (3) merupakan pendingin berupa air ringan.

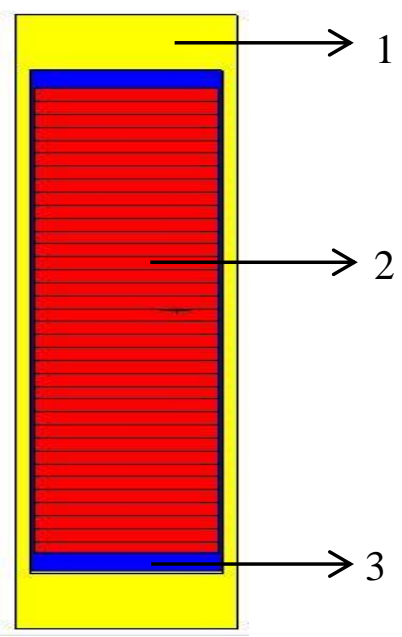

Gambar 3. Geometri pin bahan bakar uji

Pin bahan bakar uji $\mathrm{UO}_{2}$ dimasukkan pada fasilitas PRTF teras RSG-GAS. Selanjutnya, pin bahan bakar uji $\left(\mathrm{UO}_{2}\right)$ diposisikan pada $(0,20,40,60,80,100,120,140) \mathrm{mm}$ dari teras reaktor. Running dilakukan pada setiap posisi pin. Pada posisi terdekat dari teras yaitu $0 \mathrm{~mm}$ ditunjukkan pada Gambar 4.

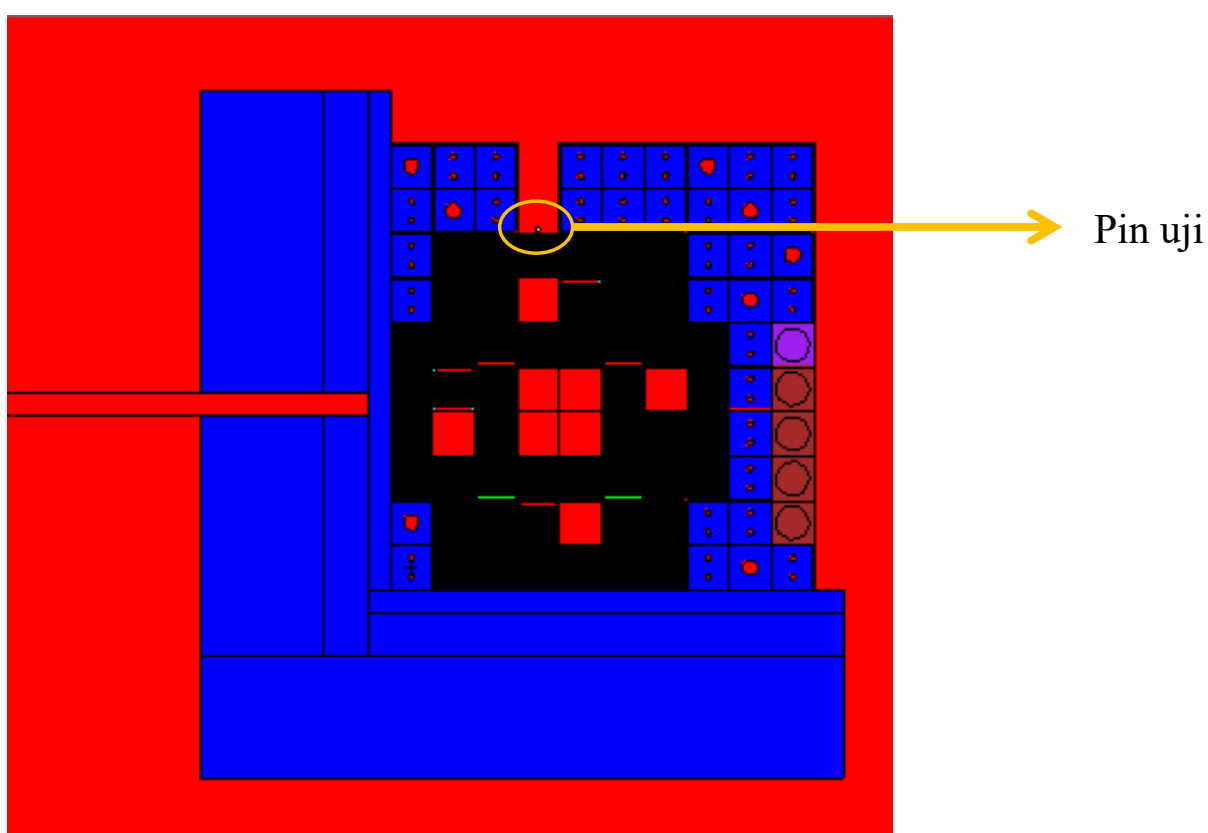

Gambar 4. Penyisipan pin bahan bakar uji PRTF pada teras RSG-GAS di koordinat XY posisi $0 \mathrm{~mm}$.

\subsection{Nilai $\boldsymbol{k}_{\text {eff }}$ pada berbagai posisi pin}

Hasil simulasi perhitungan $k_{\text {eff }}$ disajikan pada Tabel 2. dan dibuat grafik yang ditunjukkan pada Gambar 5.

Tabel 2. Hasil simulasi perhitungan $k_{e f f}$ 


\begin{tabular}{ccc}
\hline Posisi $(\mathbf{m m})$ & $\boldsymbol{k}_{\boldsymbol{e f f}}$ & Standar Deviasi \\
\hline $\mathbf{0}$ & 1,10303 & 0,00007 \\
$\mathbf{2 0}$ & 1,10339 & 0,00007 \\
$\mathbf{4 0}$ & 1,10332 & 0,00007 \\
$\mathbf{6 0}$ & 1,10303 & 0,00007 \\
$\mathbf{8 0}$ & 1,10279 & 0,00007 \\
$\mathbf{1 0 0}$ & 1,10261 & 0,00008 \\
$\mathbf{1 2 0}$ & 1,10253 & 0,00007 \\
$\mathbf{1 4 0}$ & 1,10245 & 0,00007 \\
\hline
\end{tabular}

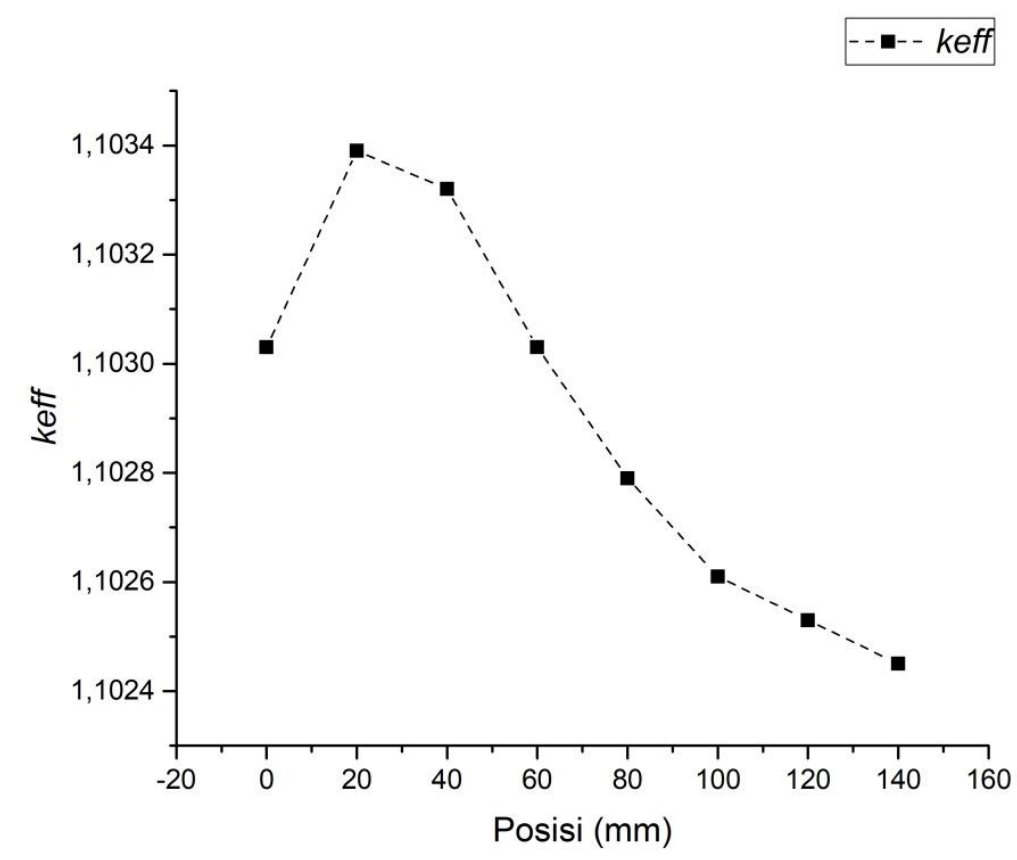

Gambar 5. Grafik nilai $k_{e f f}$ pada berbagai posisi pin

Nilai $k_{\text {eff }}$ paling tinggi terjadi jika posisi pin 20-40 mm dari teras reaktor, semakin menuju ke arah luar teras nilai $k_{e f f}$. makin kecil. Ditinjau dari batas nilai $k_{e f f}$. diperbolehkan untuk operasi reaktor RSG GAS, nilai ini masih masuk dalam range. Nilai $k_{\text {eff }}$ ini dikonfirmasi dengan Gambar 3.4. yang menunjukkan distribusi netron pada posisi bahan bakar. Daya teras sebanding dengan fluks termal, dimana pada posisi 20-40 mm fluks netron termal mencapai kondisi optimum yang disebabkan oleh efek dari reflektor, posisi optimum dari batang penyerap yang umumnya akan menyerap netron termal. 


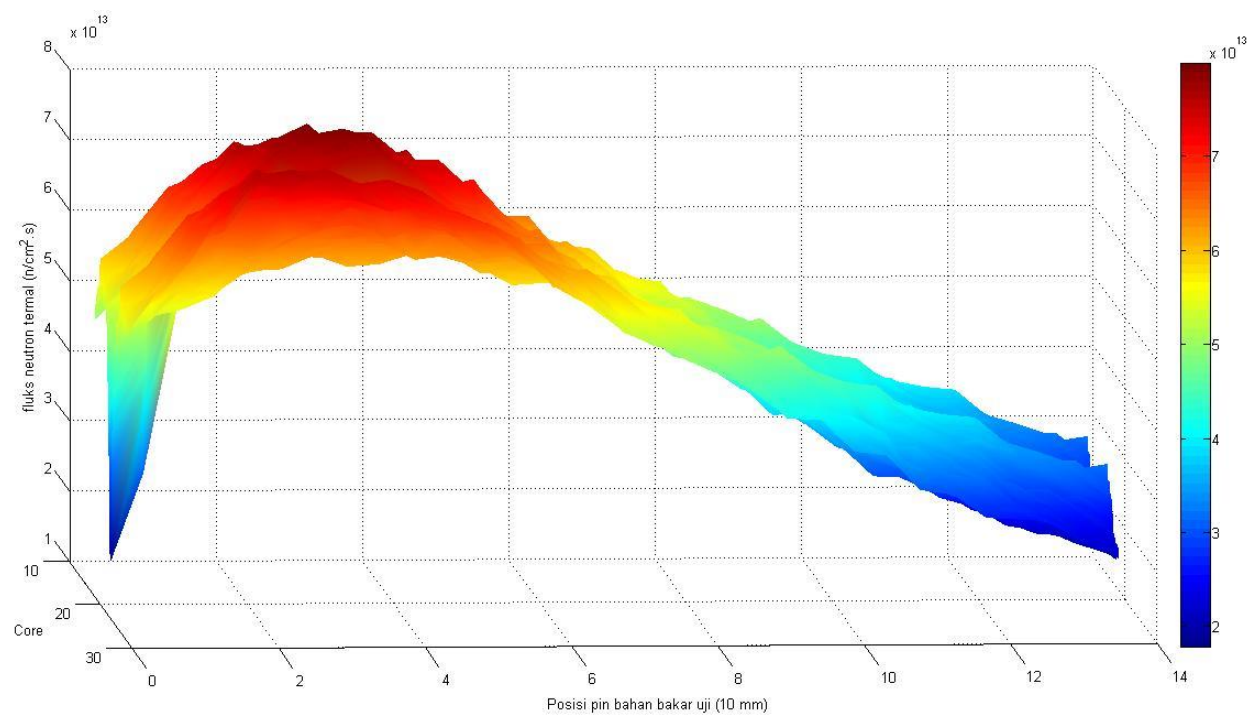

Gambar 6. Distribusi fluks neutron termal pada posisi pin bahan bakar uji

\subsection{Perhitungan Perubahan Reaktivitas $(\Delta \rho)$}

Perhitungan $\Delta \rho$ dilakukan dengan persamaan (3) dituliskan pada Tabel 3. dan dibuat grafik hubungan antara perubahan reaktivitas terhadap posisi ditunjukkan pada Gambar 3.5.

Tabel 3. Hasil Perhitungan Perubahan Reaktivitas

\begin{tabular}{ccc}
\hline Posisi (mm) & Perubahan Reaktivitas $(\% \Delta \boldsymbol{k} / \boldsymbol{k})$ & Standar Deviasi \\
\hline $\mathbf{0}$ & 0,05675 & 0,00006 \\
$\mathbf{4 0}$ & 0,08633 & 0,00006 \\
$\mathbf{6 0}$ & 0,08058 & 0,00006 \\
$\mathbf{8 0}$ & 0,05675 & 0,00006 \\
$\mathbf{1 0 0}$ & 0,03702 & 0,00006 \\
$\mathbf{1 2 0}$ & 0,02221 & 0,00007 \\
$\mathbf{1 4 0}$ & 0,01563 & 0,00006 \\
\end{tabular}




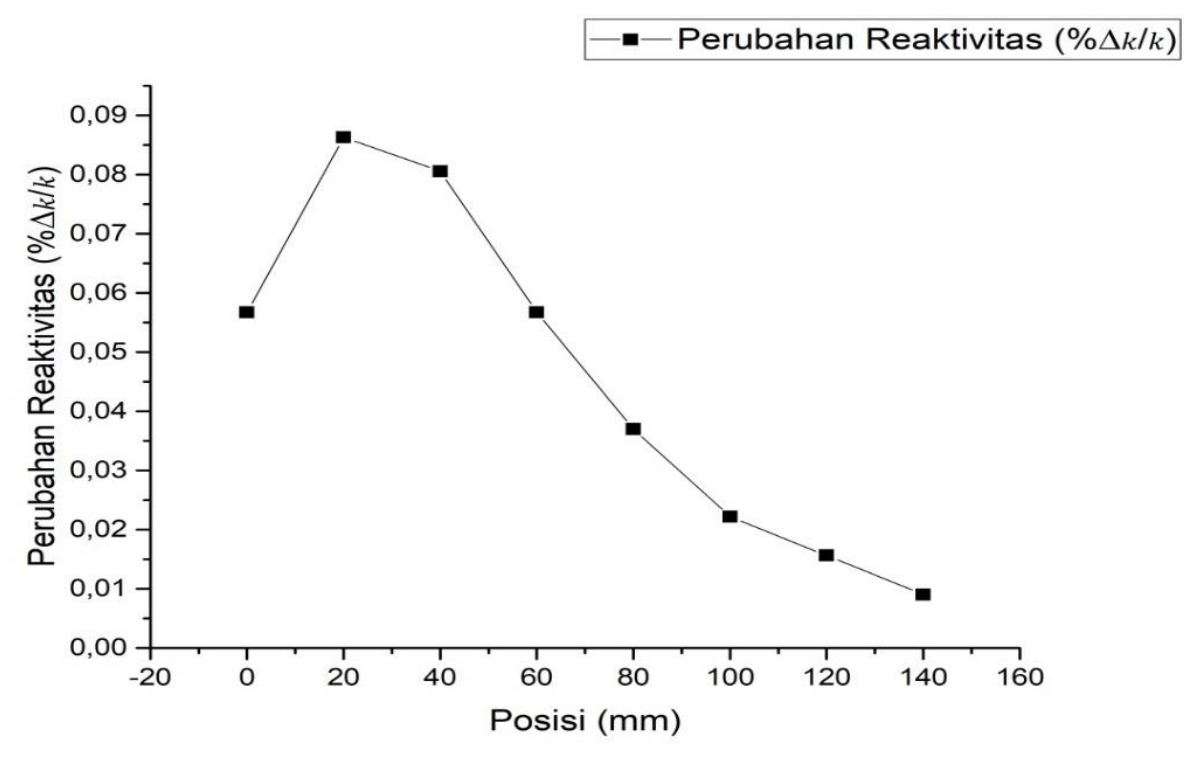

Gambar 7. Grafik $\Delta \rho$ perubahan reaktivitas pada berbagai posisi

Batas maksimal nilai $\Delta \rho$ untuk operasi reaktor adalah $0,5 \% \frac{\Delta k}{k}$. Nilai tertinggi $\Delta \rho$ akibat masuknya pin bahan bakar juga terjadi di posisi pin 20-40 mm, nilai maksimal adalah $0,08633(\% \Delta k / k)$. Ditinjau dari nilai $\Delta \rho$ maka masuknya pin bahan bakar di PRTF tidak menganggu keselamatan reaktor RSG-GAS.

\section{KESIMPULAN}

Secara kajian nilai $k_{e f f}$ dan $\Delta \rho$ masuknya pin bahan bakar dengan pengkayaan $5 \%$ di PRTF tidak menganggu keselamatan reaktor RSG-GAS. Nilai $k_{e f f} \quad$ dan $\Delta \rho$ tertinggi terjadi apabila pin bahan bakar berada pada jarak 20-40 $\mathrm{mm}$ dari teras reaktor.

\section{SARAN}

Kajian keselamatan reaktor dapat dilengkapi dengan menambahkan kajian dari besaran lainnya, seperti perhitungan distribusi fluks neutron, distribusi daya, suhu pada reaktor, dan unsur radioaktif yang terbentuk dalam reaktor.

\section{DAFTAR PUSTAKA}

DOE Fundamentals handbook. (1993). Neclear physics and reactor theory Vol 2. Washington DC: Department of energy.

Fadli. O.E., Suparmi, Khakim. A., Suharyana, \& Riyatun. (2019). Distribution Analysis in the RSGGAS Reactor: Preliminary Study to Identify the Reactor Readiness as Power Ramp Test Facility (PRTF). Journal of Physics: Conference Series 1153012111.

Kuntoro, Iman. (2017). Keselamatan Reaktor Nuklir: Reaktor Serba Guna G.A Siwabessy (RSGGAS). Jakarta: BATAN Press.

Iman, J., Hartaman, S., \& Sihombing, E. (2015). Evaluasi Fluks Neutron Termal di Fasilitas PRTF Reaktor RSG-GAS. Yogyakarta.: Seminar Nasional XI SDM Teknologi Nuklir.

Yulianto, Y. E., \& Imron, M. (2013). Manajemen Pengoperasian Reaktor RSG-GAS. Seminar Nasional Teknologi dan Aplikasi Reaktor Nuklir: BATAN. 